\title{
Note
}

\section{Effects of Tritiated Water on the DNA of Plasmid pBR $322^{\circ}$}

\author{
Koichi Yoshinaga, Hideyuki TAMI* and Kunihiko HasegawA* \\ Department of Chemistry, *Radiochemistry Research Laboratory, Shizuoka University \\ 836, Ooya, Shizuoka-shi 422, Japan \\ Received February 4, 1984
}

\begin{abstract}
In an attempt to shed light on the influence of tritiated water for DNA we have investigated the damage with a simple plasmid DNA, pBR 322. The survival of covalently closed circular (CCC DNA) form was directly followed by agrose gel electrophoresis. It was found that the survival percentage of DNA in tritiated water was observed almost the same as the irradiation of $X$-rays at the same absorbed doses. For the irradiation of $\gamma$-rays, on the other hand, the decay rate was larger than those of both tritiated water and $X$-rays. The yields percentage of the broken pieces of DNA in tritiated water, $X$-rays and $\gamma$-rays were found to be 43, 38 and $33 \%$ at $10^{4}$ rad of the absorbed dose. It may be considered that the degree of danger in tritiated water is quite larger than that of $\gamma$-rays. It was also found that the dose rate effect was not observed in the case of tritiated water, $X$-rays and $\gamma$-rays irradiation.
\end{abstract}

Key Words: tritiated water, plasmid, DNA break

\section{Introduction}

In recent year, the developing nuclear fusion reactor studies have been prosperous in many countries in the world. The most important stuff in its studies, tritium, has been remarkably noted in the fundamental investigations in the field of physics, chemistry and biology. It is considered that there are many problems left unsolved, particularly, such as its influence on human body. The radiobiological effectiveness (RBE) or quality factor (Q) of tritium is known between 1.0 and $1.7^{1)}$.

In the present paper, we compared the damage of DNA when it was immersed in the tritiated water and that in the case of irradiation of $\gamma$-rays and $\mathrm{X}$-rays.

\section{Experimental}

The tritiated water used was obtained from the Radiochemical Centre (Amersham, England)

†プラスミドDNA pBR 322 に対するトリチウム水 の効果。吉永光一, 田見秀行*, 長谷川圆彦*: 静 岡大学理学部, *理学部附属放射化学研究施設, 422 静岡市大谷 836 。 and its radioactive concentration was determined with a liquid scintillation counter. The radioactive concentration was $222 \mathrm{MBq} / \mathrm{ml}(6 \mathrm{mCi}$ / $\mathrm{m} l)$. The absorbed dose rate of tritiated water, $R$, is given by $R=0.593 \times C \times \bar{E} \mathrm{rad} / \mathrm{s}$, where $\bar{E}$ is the average $\beta$-ray energy $(0.0057 \mathrm{MeV})$ of tritium and $C$ the radioactive concentration $(\mathrm{mCi} / \mathrm{ml})$ of the sample.

In experimental procedures, the tritiated water was diluted with water which was obtained from Millipore Milli-Q system. DNA used was plasmid pBR $322^{2), 3)}$, which was phenolized one, and was obtained as a generous gift from Professor W. Messer (Max-Planck-Institut für Molekulare Genetik, Berlin). DNA was stored in TE buffer $(10 \mathrm{mM}$ tris $\mathrm{HCl}, \mathrm{pH} 7.5,1 \mathrm{mM}$ EDTA) at the concentration of $0.5 \mathrm{mg} / \mathrm{ml}$ at $4^{\circ} \mathrm{C}$ and was diluted with the same volume of pure water just before irradiation. Thus prepared DNA was mainly covalenty closed circular (CCC), with a slight trace of open one (OC). Linear form of DNA was obtained by restriction-endonuclease EcoR1 digestion. The tritiated water with two kinds of the radioactive concentrations was used. One is the radioactive 
concentration of $222 \mathrm{MBq} / \mathrm{ml}(6 \mathrm{mCi} / \mathrm{ml})$, and $5 \mu l$ DNA were pored into Eppendrof microtube. The mixed solution was kept for $2 \sim 12$ days in a dark place at $4{ }^{\circ} \mathrm{C}$. In another case of using $22.2 \mathrm{MBq} / \mathrm{ml}(0.6 \mathrm{mCi} / \mathrm{ml})$ tritiated water, in the same procedure as mentioned above, the solution was kept for 5 25 days. As the control experiment, the stability of DNA with non-radioactive water was studied for each standing time. It was found that $2 \%$ of $\mathrm{CCC}$ DNA turned into OC form after 25 days. X-rays irradiation was performed with instrument (Toshiba type KXC-18) under the conditions of the tube voltage of $180 \mathrm{KVp}$ and with no filter. The dose rate of X-rays was measured with Fricke dosimeter $(G=15.5)$. The results obtained was $3.92 \mathrm{~Gy} / \mathrm{min}(392 \mathrm{rad} / \mathrm{min})$. A box made of acrylic acid resin was put on the samples to avoid influence of a secondary electron generated by X-rays. The total doses were varied from 19.60 to $117.60 \mathrm{~Gy}$ ( 1960 to $11760 \mathrm{rad}$ ). $\mathrm{Ir}-$ radiation by ${ }^{60} \mathrm{Co} \gamma$-rays was done at three kinds of dose rates, i.e., 29, 250, $490 \mathrm{mGy} / \mathrm{min}$ (2.9, 25.0 and $49.0 \mathrm{rad} / \mathrm{min}$ ). All of the irradiated DNA samples were subjected to electrophoresis on a horizontal agrose gels. Gels $(10 \times 10 \times 3$ $\mathrm{mm}$ ) contained $1 \%$ agrose (Bio. Rad. Laboratories, Richmond Calif., U.S.) in electrophoresis

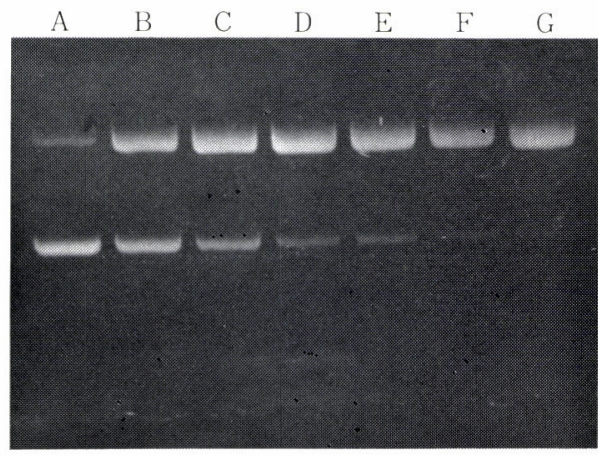

Fig. 1 Agarose-gel electrophoresis of plasmid DNA irradiated with $\mathrm{X}$-rays. DNA samples were irradiated with the various doses of $\mathrm{X}$-rays, A, $0 \mathrm{rad}$ (control), B, $1960 \mathrm{rad}, \mathrm{C}, 3920$ $\mathrm{rad}, \mathrm{D}, 5880 \mathrm{rad}, \mathrm{E}, 7840 \mathrm{rad}, \mathrm{F}, 9800 \mathrm{rad}$, $\mathrm{G}, 11760 \mathrm{rad}$. They were applied to $1 \%$ agarose-gel and electrophoresis was done from top to bottom. CCC DNA, OC DNA and linear DNA were observed in lower, upper and middle bands respectively.

$(100 \mathrm{rad}=1 \mathrm{~Gy})$ buffer (40 $\mathrm{mM}$ tris-acetate pH 7.9, $10 \mathrm{mM}$ Na-acetate, $1 \mathrm{mM}$ EDTA, $1 \mu \mathrm{g} / \mathrm{m} l$ ethidiumbromide). Each samples with $5 \mu l$ of dye solution ( $7 M$ urea, $50 \%$ sucrose, $0.1 \mathrm{mM}$ EDTA $0.1 \%$ bromophenol blue) was applied to a slot of the gel. Electrophoresis was performed at $100 \mathrm{~mA}$ for $1.5 \mathrm{~h}$. The DNA bands, visualized as luminescence by transmitting ultraviolet light of long wave length, were recorded on Polaroid films (type-665). Figure 1 shows the picture in the case of irradiation of X-rays. Three forms of DNA were clearly separated from each other. CCC DNA, OC DNA and linear DNA were obseved in lower, upper and middle band, respectively.

DNA amount of each form was measured by scanning the negative films with a multi-purpose spectrophotometer at $600 \mathrm{~nm}$ of the wavelength. The films were chosen which gave the proportional relationship between the absorbance and the amount of DNA.

\section{Results and Discussion}

Figure 2 indicates the relations between absorbed dose in tritiated water and the survival percentage of CCC DNA. It is clear, however, that CCC DNA decreases with the increase of absorbed doses. In both of dose rates, 8.30 Gy/day (830 rad/day) and $830 \mathrm{mGy} /$ day (83.0 rad/day), the dose rate dependence was not observed. It was expected that the decay rate would obey the single hit kinetics, however, the rate was observed to be smaller when the high doses were applied. This is

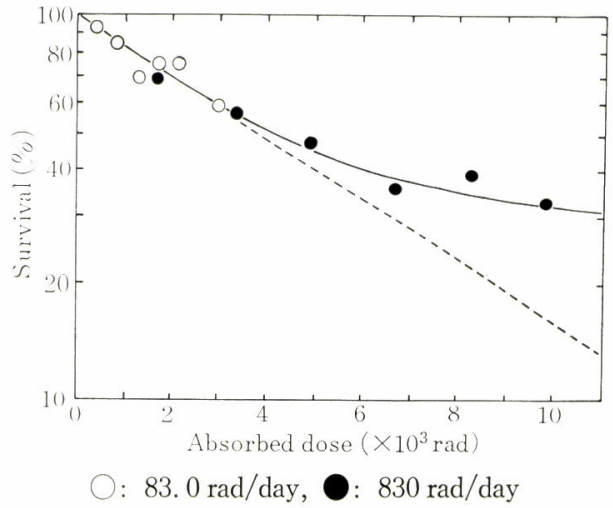

Fig. 2 Plots of the absorbed dose against survival percentage of CCC DNA for tritiated water. $\left(10^{3} \mathrm{rad}=10 \mathrm{~Gy}\right)$ 
supposed to be caused by the fact that DNA scission brings about the different length of DNA at the higher doses. The resulting heterogeneous length of DNA would spread over the track of the gel and would not be detected. Therefore, it is reasonable to suppose that the true reducing rate of survival at the higher doses is the same as that at lower doses, as shown by the dotted line.

The survival percentage against the various absorbed doses of X-rays was plotted. The results obtained was almost the same as that of tritiated water. However, the energy of Xrays used was $186 \mathrm{keV}$ which was ten times higher than that of tritium.

In the case of irradiating $\gamma$-rays, as is evident from Fig. 3, the decay rate is larger than those of both tritiated water and X-rays. It is also found that the decay rate becomes smaller when the high doses were applied. In comparison with both $\mathrm{X}$-rays and tritiated water, at more than $30 \mathrm{~Gy}\left(3 \times 10^{3} \mathrm{rad}\right)$, it was found that the observed decay rate is somewhat larger. Dose rate effect was also scarcely observed.

In irradiating DNA by the various radiations, it may be considered that the broken pieces of DNA is almost incapable of being repaired in cells. It can be assumed that there is close relationship in regards to lethal effect in cell $^{4), 5}$. In order to compare the degree of damage in the various radiations of different quality, the yield percentage of the broken pieces of DNA at $100 \mathrm{~Gy}\left(10^{1} \mathrm{rad}\right)$ of absorbed dose was estimated from the equation; Broken pieces of DNA/total DNA $=($ observed survival $\%$ - real survival $\%$ )/observed survival\%, in which the real survival\% was calculated from the dotted

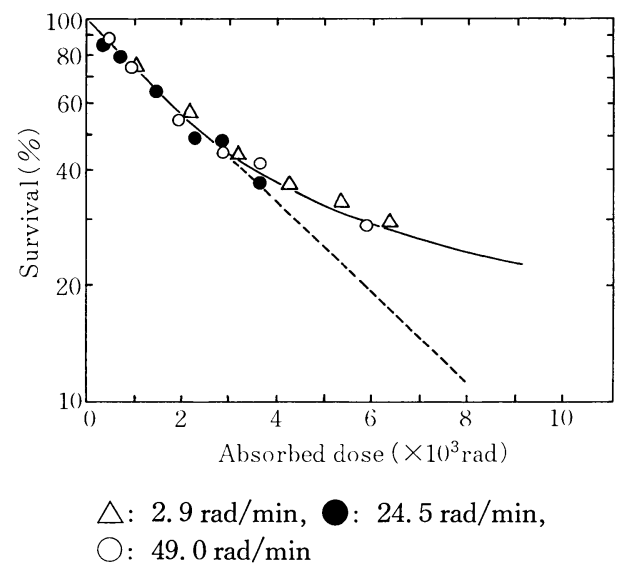

Fig. 3 Plots of the absorbed dose against survival percentage of CCC DNA for irradiation of $\gamma$-rays. $\quad\left(10^{3} \mathrm{rad}=10 \mathrm{~Gy}\right)$

line. The yields for tritiated water, X-rays and $\gamma$-rays were 43,38 and $33 \%$ respectively. As is evident from these values, the value for tritiated water is the biggest. It may be concluded that the degree of danger in tritiated water is quite larger than those of $\mathrm{X}$ - and $\gamma$-rays.

\section{References}

1) Tritium in the Environment, NCRP Report No. 62, 52 (1979)

2) Bolivar, F., et al.: Gene, 2, 95 113 (1977)

3) Sutcliffe, J. G.: Cold Spring Harbor Symp. Quantitative Biol., 43, 77 90 (1978)

4) McGrath, R. A. and Williams, R. W.: Nature, 212, 534 35 (1966)

5) Yoshinaga, K.: Biochim. Biophys. Acta, 294, 204 13 (1973) 